NUREG-1461

\title{
Regulatory Analysis for the Resolution of Generic Issue 153: Loss of Essential Service Water in LWRs
}

Manuscript Completed: July 1993

Date Published: August 1993

T.-M. Su

Division of Safety Issue Resolution

Office of Nuclear Regulatory Research

U.S. Nuclear Regulatory Commission

Washington, DC 20555-0001
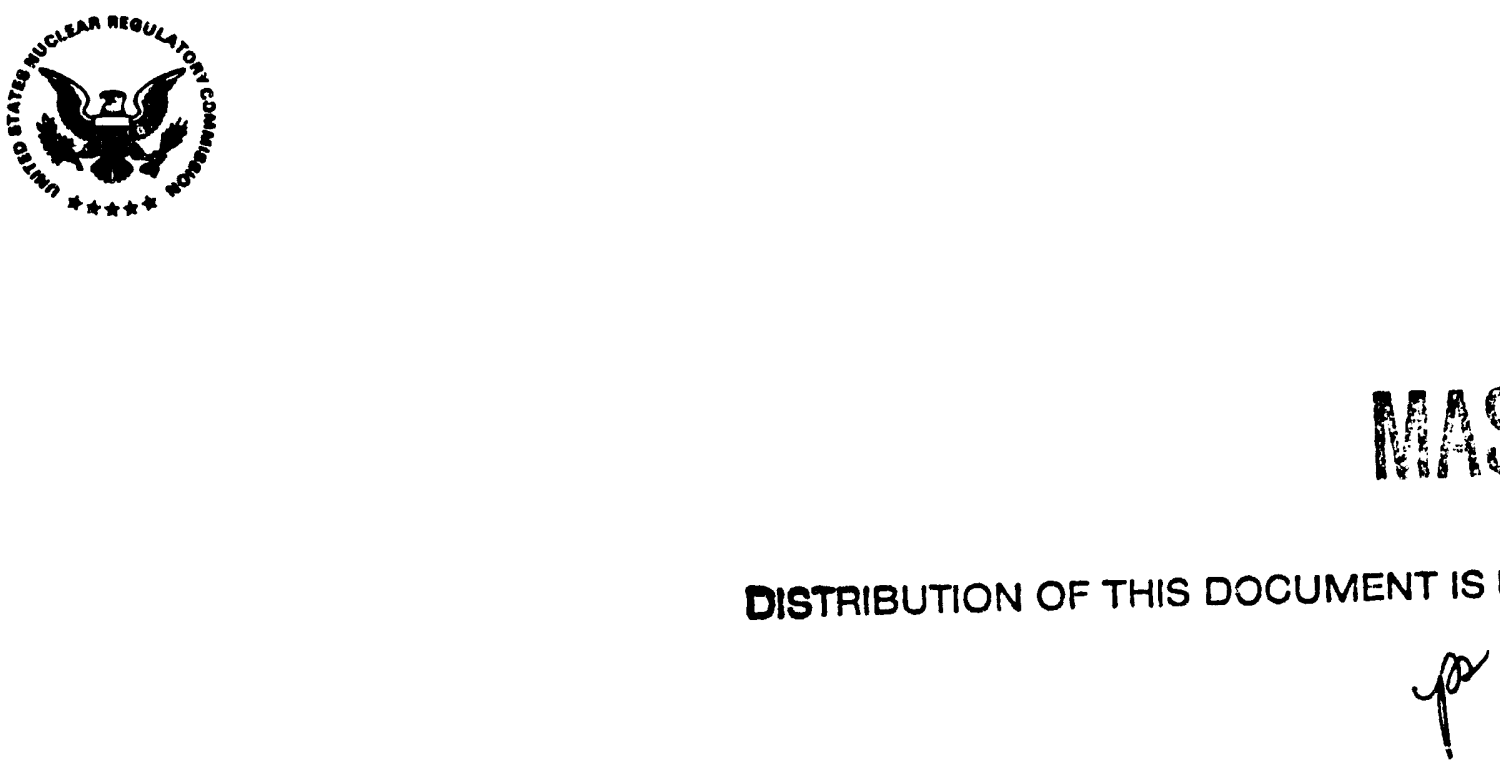


\begin{abstract}
In this report, the stafl of the U.S. Nuclear Regulatory Commission (NRC) provides at regulatory analysis for the proposed resolution of Generic Issue 153 (GI-153), "Loss of Essential Service Water in LWRs." GI-153 deals with the concerns pertaining to the reliability of essential service water (ESW) system and related problems for all light water reactors except the seven multi-unit sites addressed by GI-130, "Essential Service Water Pump Failures at Multi-Unit Sites." On the basis of the technical findings

of a scoping study for GI-153, the staff recommends that the insights gained from the study serve as a complement to the on-going ESW performance inspection program. The staff also concludes that ESW system reliability is being addressed by various on-going regulatory programs. Therefore, the staff recommends that GI- 153 should be considered "RESOLVED." The need for future action(s) on ESW reliability is expected to be determined from these on-going programs.
\end{abstract}




\section{CONTENTS}

Page
Pa.

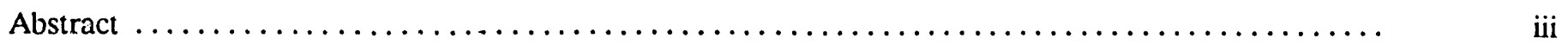

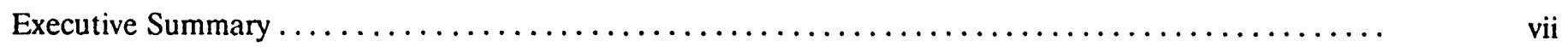

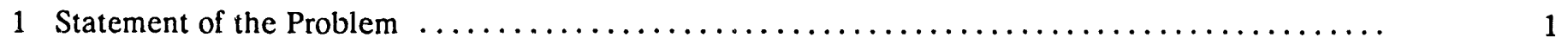

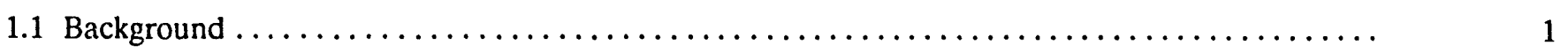

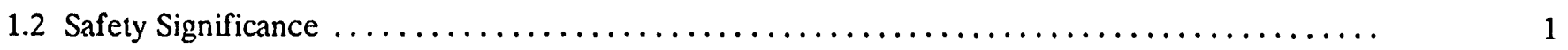

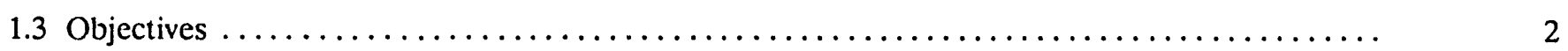

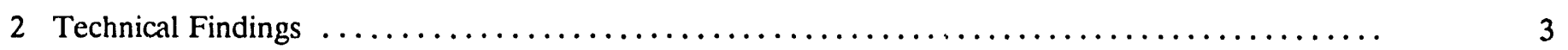

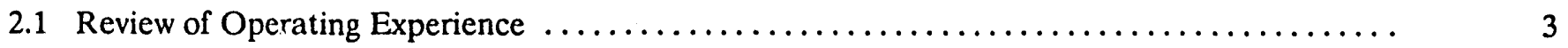

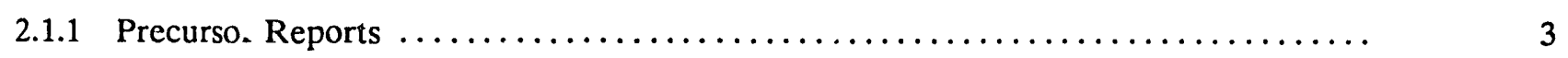

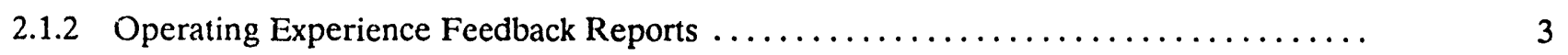

2.1.3 Analysis of ESW System at Multi-Unit Sites $\ldots \ldots \ldots \ldots \ldots \ldots \ldots \ldots \ldots \ldots \ldots \ldots \ldots$

2.1.4 Operating Experience after Publication of NUREG-1275 (1987-1992) ........... 3

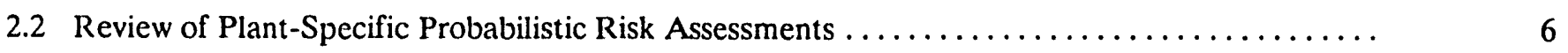

2.2.1 Contribution of ESW system to Risk of Core Damage .................. 6

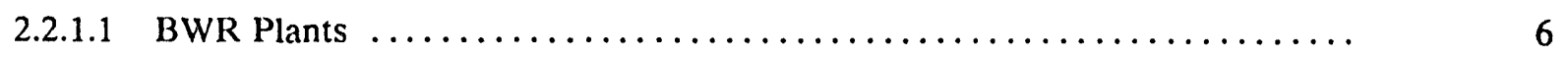

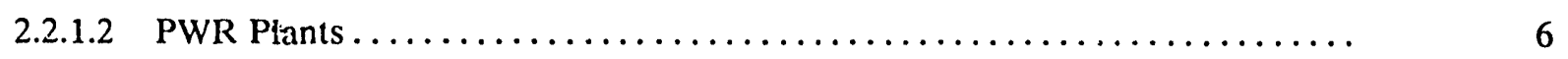

2.2.2 Discussion of Plant-Specific Probabilistic Risk Assessments ................ 6

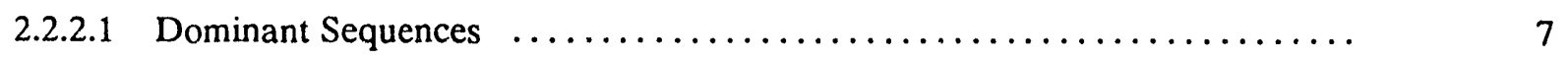

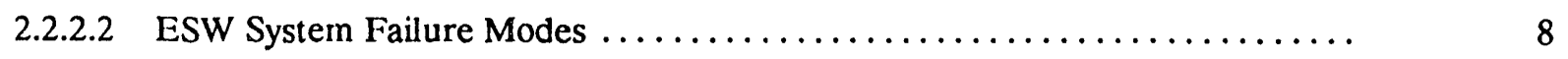

2.2.2.3 Effects of Water Quality on ESW System $\ldots \ldots \ldots \ldots \ldots \ldots \ldots \ldots \ldots \ldots$

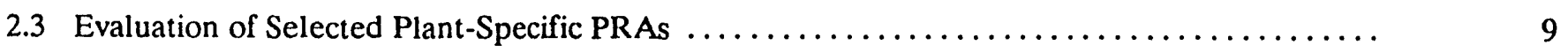

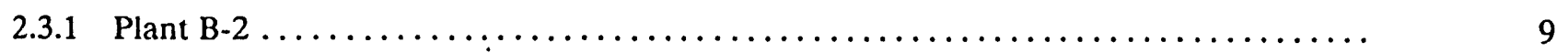

2.3.1.1 Contribution of $\mathrm{ESW}$ system to Internal Events $\mathrm{CDF} \ldots \ldots \ldots \ldots \ldots \ldots \ldots \ldots$

2.3.1.2 Contribution of ESW system to External Events CDF $\ldots \ldots \ldots \ldots \ldots \ldots \ldots \ldots$

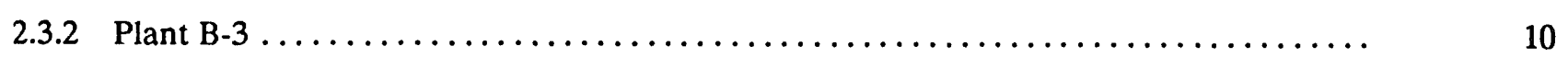

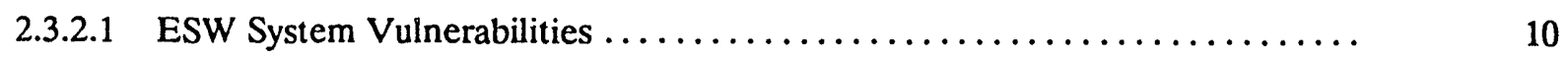

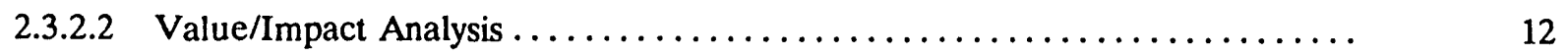

2.3.2.3 Contribution of ESW to External Events CDF $\ldots \ldots \ldots \ldots \ldots \ldots \ldots \ldots \ldots$

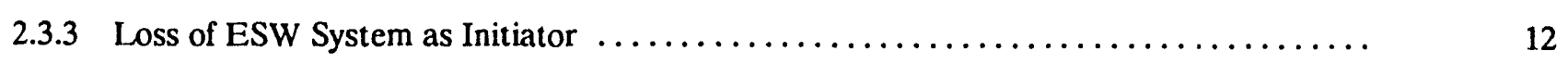

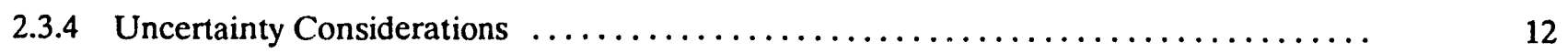

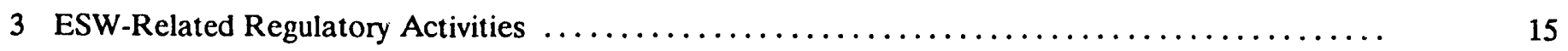

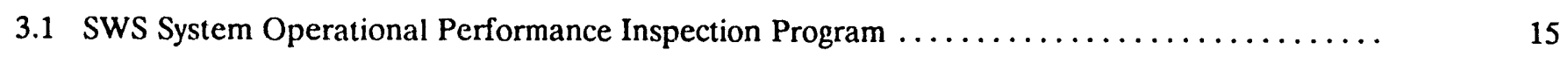

3.2 Implementation of Generic Letter $89-13$ Requirements . . . . . . . . . . . . . . . . 15

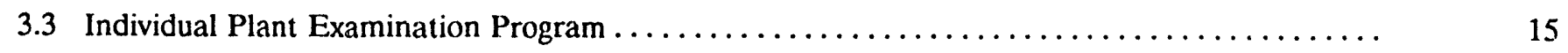




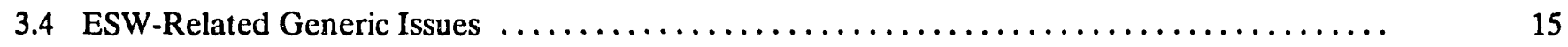

3.4.1 Generic Issue 23, "Reactor Coolant Pump Seal Failures" ................. 15

3.4.2 Generic Issue 51, "Improving the Reliability of Open Cycle Service-Water system” ... 16

3.4.3 Generic Issue 130, "Essential Service Water Pump Failures at Multi-Unit Sites”...... . 16

3.4.4 Generic Issue B-32, "Ice Effects on Safety-Related Water Supplies" ........... 16

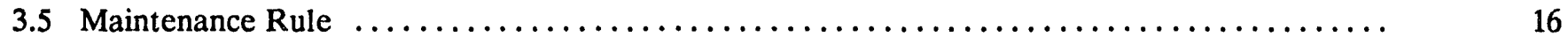

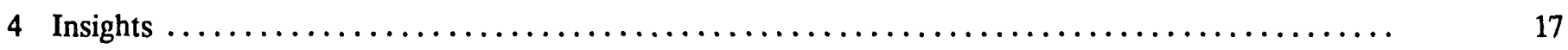

4.1 Contribution of the ESW System to the Risk of Core Damage $\ldots \ldots \ldots \ldots \ldots \ldots \ldots \ldots \ldots$

4.2 Dominant Sequences and Other Factors Influencing the ESW System Reliability ......... 17

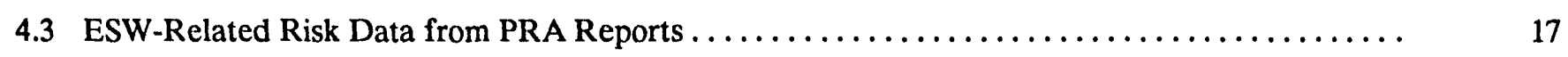

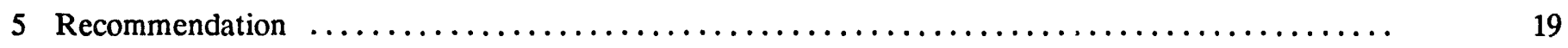

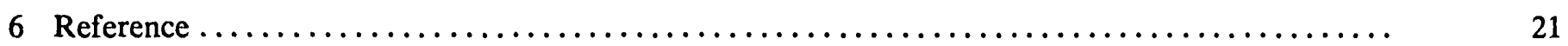

\section{List of Tables}

E.1 ESW System's Contribution to Core Damage Frequency (Internal Events) $\ldots \ldots \ldots \ldots \ldots \ldots$ viii

2.1 Precursors to Potential Severe Core Damage Accidents Involving Service Water Systems ...... 4

2.2 Twelve Events From NUREG-1275 Resulting in Complete Loss of SW Function .......... 5

2.3 Additional Events From NUREG/CR-5526 Resulting in Complete Loss of SW

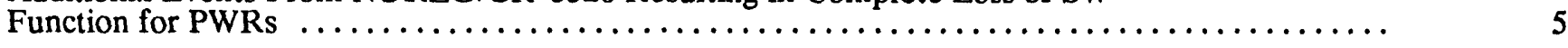

2.4 Recent Events Resulting in the Loss of SW Function $\ldots \ldots \ldots \ldots \ldots \ldots \ldots \ldots \ldots \ldots \ldots \ldots$

2.5 ESW System Contribution to Core Damage Frequency, BWRs (Internal Events) ........... 7

2.6 ESW System Contribution to Core Damage Frequency, PWRs (Internal Events) ............ 7

2.7 ESW System Failure Modes Dominant at More Than One Site $\ldots \ldots \ldots \ldots \ldots \ldots \ldots \ldots \ldots$.

2.8 ESW System Vulnerabilities and Modifications $\ldots \ldots \ldots \ldots \ldots \ldots \ldots \ldots \ldots \ldots \ldots \ldots \ldots \ldots \ldots$

2.9 Value/Impact Analysis for Individual Modification (Plant B-3) $\ldots \ldots \ldots \ldots \ldots \ldots \ldots \ldots \ldots \ldots$

2.10 ESW System Contribution to Core Damage Frequency (Plant B-3) $\ldots \ldots \ldots \ldots \ldots \ldots \ldots \ldots$

2.11 Sensitivity of Modification 2 Cost/Benefit Ratio to Variations in Assumptions for Plant B-3 ..... 14 


\section{EXECUTIVE SUMMARY}

In this report, the staff of the U. S. Nuclear Regulatory Commission (NRC) provides a regulatory analysis for the resolution of Generic Issue 153 (GI-153), "Loss of Essential Service Water in LWRs." The resolution is based on the technical findings of a scoping study for GI-153. GI-153 deals with the concerns pertaining to the reliability of essential service water (ESW) system and related problems for all light water reactors except the seven multi-unit sites addressed under GI-130, "Essential Service Water Pump Failures at Multi-Unit Sites."

The reliability of the ESW system has been a concern of the NRC and the nuclear industry for years. The NRC concerns have been addressed in research reports, bulletins, a generic letter, and generic issues. The NRC also conducted a study to evaluate the operating experience of the ESW system. In July 1989, the NRC issued Generic Letter (GL) 89-13 requesting that all licensees establish programs to improve the performance of the ESW system. The problems with this system identified in GL 89-13 include biofouling and corrosion/erosion.

The industry responded to the concerns about ESW system unavailability by supporting Electric Power Research Institute (EPRI) research programs to improve the performance of the ESW system. EPRI established a Service Water Working Group (SWWG) and Service Water Assistance Program (SWAP) to conduct ESW-related research programs, mainly to address the concerns of GL 89-13. In 1990, an EPRI-sponsored study of the ESW system reliability was completed, and the results of the study were documented in NSAC-148, "Service Water Systems and Nuclear Plant Safety." The insights gained from this study were incorporated into the GI-153 study.

For the GI-153 stucy, 11 plant-specific probabilistic risk assessments (PRAs) were reviewed to evaluate the contribution of the ESW system to the risk of core damage. The results of the review plus data from the six additional PRAs reviewed under the EPRI-sponsored NSAC-148 study indicate that this contribution is significant for some plants. The contribution of the ESW system to the risk of core damage from these 17 plant-specific PRAs considering internal events only can be divided into four groups by separating boiling water reactors (BWRs) from pressurized water reactors (PWRs) and by separating older plants from newer plants. The calculated contributions for these four groups are given in Table E-1.

As can be seen from Table E-1, there are wide variations in the estimated contribution to CDF attributed to the ESW system. The variations indicate that the impact of service water systems on plant risk is largely plant specific. The reasons for the broad range include the varying de- gree of dependency on the ESW system, the reliability of the ESW system itself, and, to some extent, the differences in the PRAs in terms of modeling assumptions and scope of each PRA program.

The ESW system dominant failure modes found from the review of the 11 NRC-sponsored PRAs have some common aspects in different plants, even though the system configuration for each plant reviewed is unique. For instance, one of the common service water faults was the failure of the service water system motor-operated or air-operated isolation valves to open on demand to supply cooling water to safety-related loads. This failure mode was identified in three BWRs and two PWRs. However, no single common failure mode for all the 11 PRAs was found.

A pilot plant, which is an older BWR-4, was selected from the 11 PRAs for a value/impact analysis. As a result of the analysis, the ESW system vulnerabilities were identified and modifications were developed to address them. By using the NRC-sponsored PRA (NUREG-1150), the effects of one or more of these modifications were then incorporated into the service water fault trees to calculate the change in plant $\mathrm{CDF}$.

Some modifications could be cost effective for the pilot plant. For example, the addition of standby auto-actuation logic would reduce the potential auto-start failure of an emergency service water pump following a loss of offsite power accident. For this modification, if implemented, the potential reduction of the plant total CDF (internal plus external events) was estimated to be $1.2 \mathrm{E}-05$ per reactor-year. The value/impact ratio for this modification was calculated to be $\$ 380$ per person-rem for a 16-year remaining lifetime. Thus, this modification represents a cost-effective measure for reducing risk based on the current $\$ 1,000$ per person-rem guideline.

On the basis of the review of all 17 plant-specific PRAs and a detailed value/impact analysis of the pilot plant, the staff concludes the following:

- The contribution of the ESW system to the risk of core damage is substantial for some plants.

- In general, the contribution of the ESW system to the risk of core damage is more significant for BWRs than PWRs, and more for the old vintage than the new.

- The impact of the ESW system on plant risk varies widely and is plant specific, primarily because of the plant-unique design of the system and the degree of dependency in the system. 
Table E-1 ESW System's Contribution to Core Damage Frequency (Internal Events)

\begin{tabular}{|c|c|c|c|c|}
\hline Plant & Type & $\begin{array}{c}\text { Total CDF } \\
\text { (Internal } \\
\text { Events) }\end{array}$ & $\begin{array}{c}\text { ESW CDF } \\
\text { Contribution } \\
\text { (Internal } \\
\text { Events) }\end{array}$ & $\begin{array}{c}\text { ESW System } \\
\text { \% } \\
\text { Contribution }\end{array}$ \\
\hline \multirow[t]{2}{*}{ BWRs } & Older & $\begin{array}{c}4.5 \mathrm{E}-06 \\
\text { to } \\
4.7 \mathrm{E}-04\end{array}$ & $\begin{array}{c}1.4 \mathrm{E}-06 \\
\text { to } \\
2.7 \mathrm{E}-04\end{array}$ & $\begin{array}{l}30 \\
\text { to } \\
65\end{array}$ \\
\hline & Newer & $\begin{array}{c}4.1 \mathrm{E}-06 \\
\text { to } \\
3.0 \mathrm{E}-04\end{array}$ & $\begin{array}{c}5.6 \mathrm{E}-07 \\
\text { to } \\
3.0 \mathrm{E}-05\end{array}$ & $\begin{array}{l}14 \\
\text { to } \\
26\end{array}$ \\
\hline \multirow[t]{2}{*}{ PWRs } & Older & $\begin{array}{c}4.0 \mathrm{E}-05 \\
\text { to } \\
3.7 \mathrm{E}-04\end{array}$ & $\begin{array}{c}1.5 \mathrm{E}-08 \\
\text { to } \\
6.7 \mathrm{E}-05\end{array}$ & $\begin{array}{l}<1 \\
\text { to } \\
19\end{array}$ \\
\hline & Newer & $\begin{array}{c}1.4 \mathrm{E}-05 \\
\text { to } \\
1.7 \mathrm{E}-04\end{array}$ & $\begin{array}{c}2.4 \mathrm{E}-07 \\
\text { to } \\
1.6 \mathrm{E}-05\end{array}$ & $\begin{array}{l}<1 \\
\text { to } \\
19\end{array}$ \\
\hline
\end{tabular}

- The ESW system dominant failure modes found from the review of the 11 NRC-sponsored PRAs have some common aspects in different plants, even though the system configuration for each plant reviewed is unique.

In addition to the GI-153 study, there are several on-going ESW-related regulatory activities. These activities include the Individual Plant Examination (IPE) program, Generic Issue 23, "Reactor Coolant Pump Seal Failures," and the most recently developed Service Water System Operational Performance Inspections (SWSOPI) program (SECY-92-355). The objectives of the SWSOPI program include: (1) to identify and evaluate ESW design vulnerabilities; (2) to assess the ESW operation, maintenance and personnel training; and (3) to assess the ESW unavailability due to maintenance and component failure. GI-23 is proposing a rule-making to require means to mitigate the risk from failure of reactor-coolant-pump seal cooling. One way to accomplish this could be to reduce the dependence on the ESW system. These regulatory activities will directly or indirectly affect the assessment of the ESW system contribution to CDF. The staff recommends that the insights from GI-153 regarding the contribution of the ESW system to the risk of core dam- age serve as a complement to the SWSOPI program to assist in such areas as determining inspection priorities. Other GI-153 information such as dominant sequences, ESW failure modes, and the effects of water quality could also assist the program in identifying and evaluating ESW vulnerabilities. In addition we note that the plant-specific PRA developed under the Individual Plant Examination (IPE) program is also a meaningful complement to the SWSOPI program to achieve one of its objective, i.e., to identify and evaluate the ESW system vulnerabilities.

With due regard for the insights from GI-153, the ESW system operability, availability and reliability can be improved significantly by implementing the SWSOPI program, Generic Letter 89-13 requirements, the IPE program, the GI-23 rule-making, the maintenance rule, and the industry sponsored EPRI research program results. Therefore, the staff concludes that ESW system reliability is being adequately addressed by the on-going regulatory and industry initiatives. As a result, the objective of GI-153 is achieved and the issue should be considered "RESOLVED." The need for future action(s) on ESW system reliability is expected to be determined from these on-going programs. 


\section{STATEMENT OF THE PROBLEM}

\subsection{Background}

The NRC and the nuclear industry have been concerned about the reliability of the essential service water (ESW) system for years. The NRC concerns have been expressed in research reports (Ref. 1 and 2), bulletins (Ref. 3 and 4), a generic letter (Ref. 5), and generic issues (Ref. 6). The NRC also conducted a study to evaluate the operating experience of the ESW system (Ref. 7). The study showed that 980 operating events in which the ESW system has failed to operate as designed had occurred; 12 of these events were considered as a complete loss of the ESW system. The causes of the system's failure and degradation include various fouling mechanisms (deposition of sediment, biofouling, corrosion and erosion, and intrusion of foreign material and debris), single failures and other design deficiencies, flooding, multiple equipment failures, and personnel and procedural errors.

The industry responded to the concerns regarding the unavailability of the ESW system by supporting EPRI research programs to improve the performance of the ESW system. EPRI established a Service Water Working Group to conduct ESW-related research programs, mainly to address the concerns of GL 89-13 (Ref. 5). In 1990, an EPRI-sponsored study on the ESW system reliability was completed and the results were documented in NSAC-148, "Service Water Systems and Nuclear Plant Safety" (Ref. 8). For this study, six plant-specific PRAs were evaluated to assess the contribution of the ESW system to the risk of core damage.

In 1991, the NRC staff completed a study pertaining to an ESW-related generic issue, GI-130, "Essential Service Water Pump Failures at Multi-Plant Sites." The insights gained from the study indicated that the ESW system problems were safety significant and might not be confined to the seven multi-unit sites addressed under GI-130. As a result, the staff concluded that the reliability of the ESW system for all other reactors (66 PWR units and 38 BWR units) should be evaluated under a new generic issue, that is, GI-153, "Loss of Essential Service Water in LWRs." Under this generic issue, all potential causes of the unavailability of the ESW system were evaluated except that are considered to be resolved by implementing the resolutions in GL 89-13 (such as those pertaining to biofouling).

GI-153 was initiated in July 1991, and the tasks were originally divided into two phases: Phase I for a scoping study and Phase II for a generic evaluation. The Phase I scoping study was completed and was documented in NUREG/CR-5910 (Ref. 9). A supplemental study was also completed and documented in a letter report (Ref.
10). These two reports completed the Phase I study. For this study:

- Eleven NRC-sponsored PRAs were reviewed to evaluate the importance of the ESW system using contribution to core damage frequency (CDF) as a measure.

- Dominant accident sequences involving ESW system failures were identified and the causes of the system's unavailability were examined.

- A value/impact analysis was performed for a selected prototypical plant to demonstrate potential improvements of the ESW system for reducing risk.

The review of the 11 plant-specific PRAs showed that ESW system vulnerability is a significant contributor to plant CDF and that cost-effective measures for reducing risk are feasible. These insights from the Phase I scoping study and the results of the EPRI-sponsored study led the staff to conclude that there was sufficient basis to recommend a resolution for GI-153. Consequently, the Phase II (more detailed evaluations of individual plants) would not be an efficient use of added resources because the Phase I scoping study had met the objectives of the issue.

\subsection{Safety Significance}

The ESW system at a nuclear power plant supplies cooling water to transfer heat from various safety-related and non-safety-related systems and equipment to the ultimate heat sink of the plant. It takes suction from the ultimate heat sink (e.g., the ocean, bay, river, lake, pond or cooling towers), removes heat via heat exchangers from the various systems and components it serves, and discharges the water back to the ultimate heat sink. It is known by different names at various light-water-reactor plants. In PWR plants, it may be referred to as the "essential service water system", the "emergency equipment cooling water system", the "essential raw cooling water system", the "salt water cooling system", the "nuclear service water system", or others. In BWR plants, it may be referred to as the "emergency equipment cooling water system", the "standby service water system", the "plant service water system", the "residual heat removal service water system", or others.

The design and operational characteristics of the ESW system are different for PWRs and BWRs. In addition, the design and operational characteristics differ significantly from plant to plant within each of these reactor types.

The ESW system, which is a support system, is needed in every phase of plant operations. Under accident condi- 
tions, it supplics adequate cooling water to systems and components that are important to shutdown the plant safely or for mitigating the consequences of the accident. Under normal operating conditions, it provides component and room cooling (mainly via the component cooling water system). During a shutdown period, it also ensures that the residual heat is removed from the reactor core. The ESW system may also supply makeup water to fire protection systems, cooling towers, and water treatment systems at a plant.

A complete loss of the ESW system could lead to a core- damage accident, posing a significant risk to the public.

\subsection{Objectives}

The objectives of GI-153 are to (1) assess the salety significance of the loss of ESW systems in light water reactors (LWRs) and the corresponding contributions to core damage frequencies (CDFs), (2) perform a valuc/impact analysis of a prototypical plant to demonstrate the feasibility of improving the reliability of the ESW system, and (3) propose a viable resolution for the issuc. 


\section{TECHNICAL FINDINGS}

This section presents the technical findings from the Phase I scoping study and the supplemental study on GI-153. The detailed descriptions are given in NUREG/ CR-5910 and a letter report (Ref. 9 and 10).

\subsection{Review of Operating Experience}

Several studies have addressed the operating experience related to service water system failures. The work is not detailed here, but the results are summarized. It should be noted that these studies were performed by different people for different purposes. Therefore, although some independence of analyses is observed in the studies, the results are not completely consistent.

\subsubsection{Precursor Reports}

Under the Accident Sequence Precursor Program, the staff at Oak Ridge National Laboratory reviews licensee event reports (LERs) of operating events at LWRs to identify and categorize potential precursors to severe core-damage accidents. Accident sequences considered in this program are those associated with inadequate core cooling. As a result, several status reports (Ref. 14-21) have been published that describe those events that have occurred as reported in IERs. A review of these for service water-related events showed that 24 events were directly related to this study. Table 2.1 lists these events and provides a description of each. As a group, the events represent a variety of causes.

\subsubsection{Operating Experience Feedback Reports}

NUREG-1275 (Ref. 7) is a comprehensive study of service water-related opersting events. Of the 980 events identified, 276 were considered to have potential generic safety significance. The causes of all the events were categorized as follows:

\begin{tabular}{lll}
- & fouling & $58.3 \%$ \\
- & single failures & $6.5 \%$ \\
- & multiple failures & $3.6 \%$ \\
- & personnel errors & $16.7 \%$ \\
- flooding' & $4.4 \%$ \\
\hline & seismic & $10.5 \%$
\end{tabular}

Twelve events were reported as complete loss-of-servicewater events. These events are tabulated in Table 2.2 with simplified descriptions that demonstrate the diversity of the failures. Only two of the events in Table 2.2 appear in Table 2.1. The following general observations can be made:
- The events extracted from the precursor reports were judged to be potential precursors to severe core damage accidents and did not necessarily involve complete loss of service water, either potentially or operationally. Therefore, only limited overlap with the results of NUREG-1275 should be expected.

- As indicated previously, because the studies documented in the precursor reports and NUREG-1275 were performed by different people for different purposes, different conclusions about the same events are not unexpected.

\subsubsection{Analysis of ESW System at Multi- Unit Sites}

The analysis documented in NUREG/CR-5526 (Ref. 1) showed that the dominant failures causing partial or complete loss of the ESW system are failure of traveling screens and common intake structure, failure of the ESW pumps, loss of electric power to the ESW system, and operator error related to the ESW pumps. Degradation of the ESW system was caused by sediment, corrosion, and mechanical and electrical problems associated with the ESW pumps. As in the other reports reviewed, there are no special failure modes that would change the basic approach used to analyze the pilot plant in this study.

This analysis showed that, for all PWRs, 12 operating events from the 1970's to 1990 for all the PWRs resulted in a complete loss of the ESW system function. Of these 12 events, 6 are the same events as those reported in NUREG-1275. The other six are shown in Table 2.3.

\subsubsection{Operating Experience after Publication of NUREG-1275 (1987-1992)}

In NUREG-1275, the NRC staff reported the results of a review of operating experience of commercial nuclear power plants from 1980 to 1987 . Since then, licensees have continued to experience operating problems with the ESW system (Ref. 22). The problems include inadequate flow distribution, system misalignment, fouling/ biofouling, clogged screens, design deficiencies, system degradation, maintenance or operator errors. These problems have occurred in BWR as well as PWR plants. Some of the operating events involved the complete loss or potential loss of the ESW system. As a result, the NRC staff issued Information Notice 92-49 (Ref. 23) on July 2, 1992. The operating events discussed in the information notice are summarized in Table 2.4 . 
Table 2.1 Precursors to Potential Severe Core Damage Accidents Involving Service Water Systems

\begin{tabular}{|c|c|c|}
\hline Plant & LER Number & Description \\
\hline Hatch 1 & LER 321/80-103 & Inlet strainers partially clogged. \\
\hline San Onofre 1 & LER 206/80-006 & Three salt water cooling trains failed. \\
\hline St. Lucie 1 & LER 335/80-029 & $\mathrm{RCP}$ seal cooling lost due to inadvertent valve closure. \\
\hline Calvert Cliffs 1 & LER 317/80-027 & Two service water pumps fail due to loss of compressed air. \\
\hline Pilgrim 1 & LER 293/80-070 & $\begin{array}{l}\text { Component cooling water lost due to maintenance and breaker } \\
\text { trip. }\end{array}$ \\
\hline Salem 1 & LER 272/80-060 & Lost SW to DG due to valve indicating open when actually closed. \\
\hline Kewaunee & LER 305/81-033 & Operator error-two component cooling water trains unavailable. \\
\hline San Onofre 3 & LER 262/84-035 & Operator error--outside limiting condition for operation. \\
\hline Surry 1 & LER 280/84-011 & $\begin{array}{l}\text { Operator error-safety injection pump CCW supply found } \\
\text { isolated. }\end{array}$ \\
\hline Salem 2 & LER 311/85-018 & $\begin{array}{l}\text { Operator error-maintenance and closed valve could not be } \\
\text { opened. }\end{array}$ \\
\hline LaSalle 1 & LER 373/85-045 & Loss of non-safety service water due to expansion joint failure. \\
\hline Susquehanna 2 & $\begin{array}{l}\text { LER } 388 / 85-014 \\
\text { and } 85-015\end{array}$ & Emergency service water failed during testing. \\
\hline Surry 1 & LER 280/86-0291 & Service water subsystem pump lost due to air binding. \\
\hline McGuire 2 & $\begin{array}{l}\text { LER } 370 / 87-016 \\
\text { and } 87-017\end{array}$ & Trip with service water train out for cleaning. \\
\hline Palisades & LER 255/88-021 & Incorrectly set relays could have resulted in loss of service water. \\
\hline Zion 1 & LER 295/88-019 & $\begin{array}{l}\text { Potential component cooling water failure due to design } \\
\text { deficiency. }\end{array}$ \\
\hline Davis Besse & LER 346/88-0071 & $\begin{array}{l}\text { Possible prolonged loss of instrument air would cause SW to } \\
\text { isolate. }\end{array}$ \\
\hline San Onofre & LER $361 / 88-010^{1}$ & Emergency cooling water unavailable due to low freon in chillers. \\
\hline Farley 1 and 2 & LER 348/88-0181 & Postulated loss of service water due to fire. \\
\hline Peach Bottom 2 & LER 277/89-002 & $\begin{array}{l}\text { Unacceptable emcrgency service water performance due to I\&C } \\
\text { problems. }\end{array}$ \\
\hline Calvert Cliffs 1 & LER 317/89-0231 & Potential pipe rupture could fail both service water pumps. \\
\hline Davis Besse 1 & LER 346/89-004 & Potential pipe rupture could fail both service water pumps. \\
\hline Nine Mile Point 2 & LER 410/89-002 & Potential service water and ECCS pump failure due to flnoding. \\
\hline River Bend & LER $458 / 89-020$ & $\begin{array}{l}\text { Service water flooded auxiliary building impairing electric power } \\
\text { and control. }\end{array}$ \\
\hline
\end{tabular}

'Listed in NUREG-1275 tables as a service water event involving equipment failures. 
Table 2.2 Twelve Events From NUREG.1275 Resulting in Complete Loss of SW Function

\begin{tabular}{|c|c|c|}
\hline Plant & LER Number & Description \\
\hline Oconee 1 & LER 269/86-11 & Inadequate siphon flow to service water pumps. \\
\hline Susquehanna 1 & LER 387/86-21 & All service water pumps failed due to operation below design flow \\
\hline Oyster Creek & LER $219 / 85-18$ & Heat exchanger plugged by coal tar enamel. \\
\hline Brunswick 1 & LER 325/84-01 & Entrapped air in suction header piping. \\
\hline Palisades & LER. 255/84-01 & Loss of power to service water pumps due to operator crror. \\
\hline Salem 2 & LER 311/83-32 & Service water bay flooded due to failed piping gasket. \\
\hline Salem 1 & LER $272 / 82-15$ & $\begin{array}{l}\text { Loss of vital bus when } 1 \text { train of service water out for } \\
\text { maintenance. }\end{array}$ \\
\hline Brunswick 2 & LER 324/82-05 & $\begin{array}{l}\text { All pumps failed to start due to low suction pressure and sediment } \\
\text { in sensing lines. }\end{array}$ \\
\hline Hatch 1 & LER 321/80-103 & Inlet strainers partially clogged. \\
\hline San Onofre 1 & LER 206/80-06 & One pump shaft sheared and valve in other train failed. \\
\hline Calvert Cliffs 2 & LER 318/82-34 & Failure of common valve in discharge header. \\
\hline Catawba 1 & LER $413 / 85-68$ & $\begin{array}{l}\text { Train A input valve failed to open and train B discharge valve } \\
\text { failed to open. }\end{array}$ \\
\hline
\end{tabular}

Table 2.3 Additional Events From NUREG/CR-5526 Resulting in Complete Loss of SW Function for PWRs

\begin{tabular}{lll}
\hline Plant & LER Number & Description \\
\hline Salem 1 & $\begin{array}{l}\text { NPE/PWR-2 } \\
\text { VIII-110 } \\
(1976)\end{array}$ & $\begin{array}{l}\text { Winter storm shut down the ESW system. Traveling screens } \\
\text { blocked by ice. }\end{array}$ \\
FPE/PWR-2 & $\begin{array}{l}\text { Flocding of the intake structure. } \\
\text { VIII-155 }\end{array}$ & $\begin{array}{l}\text { Vital bus 1A failed, bus 1B in maintenance, bus 1C did not } \\
\text { energize, loss of the ESW system. }\end{array}$ \\
Salem 1 & $\begin{array}{l}\text { LER-272/84-14 } \\
\text { Crystal River }\end{array}$ & $\begin{array}{l}\text { All ESW pumps are shut down, two divers drowned. } \\
\text { Traveling screens were damaged, CCW heat exchanger clogged. }\end{array}$ \\
San Onofre 2 \& 3 3 LER-361/83-72 & March 20, 1990 & $\begin{array}{l}\text { Loss of all safety ac power in cold shutdown. Cffsite power was } \\
\text { lost due to a truck accident. The emergency diesel-generator } \\
\text { tripped upon start. }\end{array}$ \\
\hline
\end{tabular}


Table 2.4 Recent Events Resulting in the Loss of SW Function

\begin{tabular}{lll}
\hline Plant & LER Number & Description \\
\hline Millstone 1 & LER 245/90-16 & $\begin{array}{l}\text { Storm-induced high winds and seas caused an excessive amount of } \\
\text { seawecd to accumulate on the traveling screcns for the service } \\
\text { water intake resulting in degraded ESW system. The operator } \\
\text { tripped the reactor from 45 percent of full power. }\end{array}$
\end{tabular}

Fitzpatrick $\quad$ LER 333/90-23

Excessive fouling on the traveling screen caused the screen to bow inward due to high differential pressure across the screen. The operator scrammed the reartor from 45 percent of full power.

ANO-1, Unit 2 LER 368/91-12

Debris from the lake bypassed the screens and clogged the service water pump strainers of both loops. The licensee declared buth loops of the service water inoperable with the reactor in startup conditions.

Nine Mile Point 1 LER 220/92-05 Complete loss of the ESW system occurred when the licensee in advertently closed all gates to the service water intake bay while the reactor was shut down.

\subsection{Review of Plant-Specific Probabilistic Risk Assessments}

\subsubsection{Contribution of ESW system to Risk of Core Damage}

For the GI-153 study, 11 plant-specific PRAs were reviewed to evaluate the contribution of the ESW system to the risk of core damage. The results of the review plus data from the six PRAs reviewed under the EPRI-sponsored study (Ref. 8) indicate that this contribution is sigrificant for some plants. The contribution of the ESW system to the risk of core damage from these 17 plant-specific PRAs can be divided into four groups by separating BWRs from PWRs and by separating older plants from newer plants, using 1976 as the dividing year.

\subsubsection{BWR Plants}

For the GI-153 study, four BWR plant-specific PRAs were reviewed. Table 2.5 tabulates the contribution of the ESW system to CDF for these four plants. Given in the table are the results of two additional BWR plant-specific PRAs reviewed under the EPRI-sponsored study (Ref. 8).

As can be seen in Table 2.5, the contribution to the total internal events CDF varies from 5.6E-07 to $3.0 \mathrm{E}-05$ per reactor-year for newer BWR plants and from 1.4E-06 to 2.7E-04 per reactor-year for older BWR plants, or ranges from 14 to 26 percent for the newr. plants and from 30 to 65 percent for older plants. The average contribution of the ESW system to plant internal events CDF is about 20 percent for the newer plants and 46 percent for the older plants.

\subsubsection{PWR Plants}

For the GI-153 study, seven PWR plant-specific PRAs were reviewed. Table 2.6 tabulates the contribution of the ESW system $t, C D F$ for these seven plants. Given in the table are four additional PWR plant-specific PRAs reviewed under the EPRI-sponsored study (Ref. 8).

As can be seen in Table 2.6 , the contribution to the total internal events $C D F$ varies from 2.4E-07 to $1.6:-05$ per reactor-year for newer PWR plants and from 1.5E-08 to 6.7E-05 per reactor-year for older PWR plants, or ranges from $<1$ to 19 percent for the newer plants and also for older plants. The average contribution of the ESW system to plant internal events CDF is about 7 percent for the newer plants and 12 percent for the older plants.

\subsubsection{Discussion of Plant-Specific Probabilistic Risk Assessments}

Tables 2.5 and 2.6 show a broad range of tiu contribution to CDF from plant to plant. This variation may be due to the degree that a plant is dependent on service water, the reliability of the ESW system itself, and to some extent, the differences in modeling assumptions and scope of cach NRC-sponsored PRA program. 'These conclusions are consistent with the observations in NSAC-148 (Ref. 8). Other observations are discussed in the following sections. 
Table 2.5 ESW System Contribution to Core Damage Frequency, BWRs (Internal Events)

\begin{tabular}{lllcc}
\hline Plant & Type & $\begin{array}{c}\text { Total CDF } \\
\text { (Internal } \\
\text { Events) }\end{array}$ & $\begin{array}{c}\text { ESW System } \\
\text { CDF } \\
\text { Contribution }\end{array}$ & $\begin{array}{c}\text { ESW System } \\
\text { \% } \\
\text { Contribution }\end{array}$ \\
\hline Plant B-1 & Older & $9.9 \mathrm{E}-05$ & $3.0 \mathrm{E}-05$ & 30 \\
Plant B-2 & Older & $2.9 \mathrm{E}-04$ & $1.9 \mathrm{E}-04$ & 65 \\
Plant B-3 & Older & $4.5 \mathrm{E}-06$ & $1.4 \mathrm{E}-06$ & 32 \\
Plant B-4 & Newer & $4.1 \mathrm{E}-06$ & $5.6 \mathrm{E}-07$ & 14 \\
Plant C* & Older & $4.7 \mathrm{E}-04$ & $2.7 \mathrm{E}-04$ & 57 \\
Plant F* & Newer & $3.0 \mathrm{E}-04$ & $3.0 \mathrm{E}-05$ & 26 \\
\hline BWR Average & & $2.0 \mathrm{E}-04$ & $8.7 \mathrm{E}-05$ & 37 \\
\hline
\end{tabular}

- Plants were identificd in NSAC-148 (Ref. 8). PRA for Plant C included internal and external events.

Table 2.6 ESW System Contribution to Core Damage Frequency, PWRs (Internal Events)

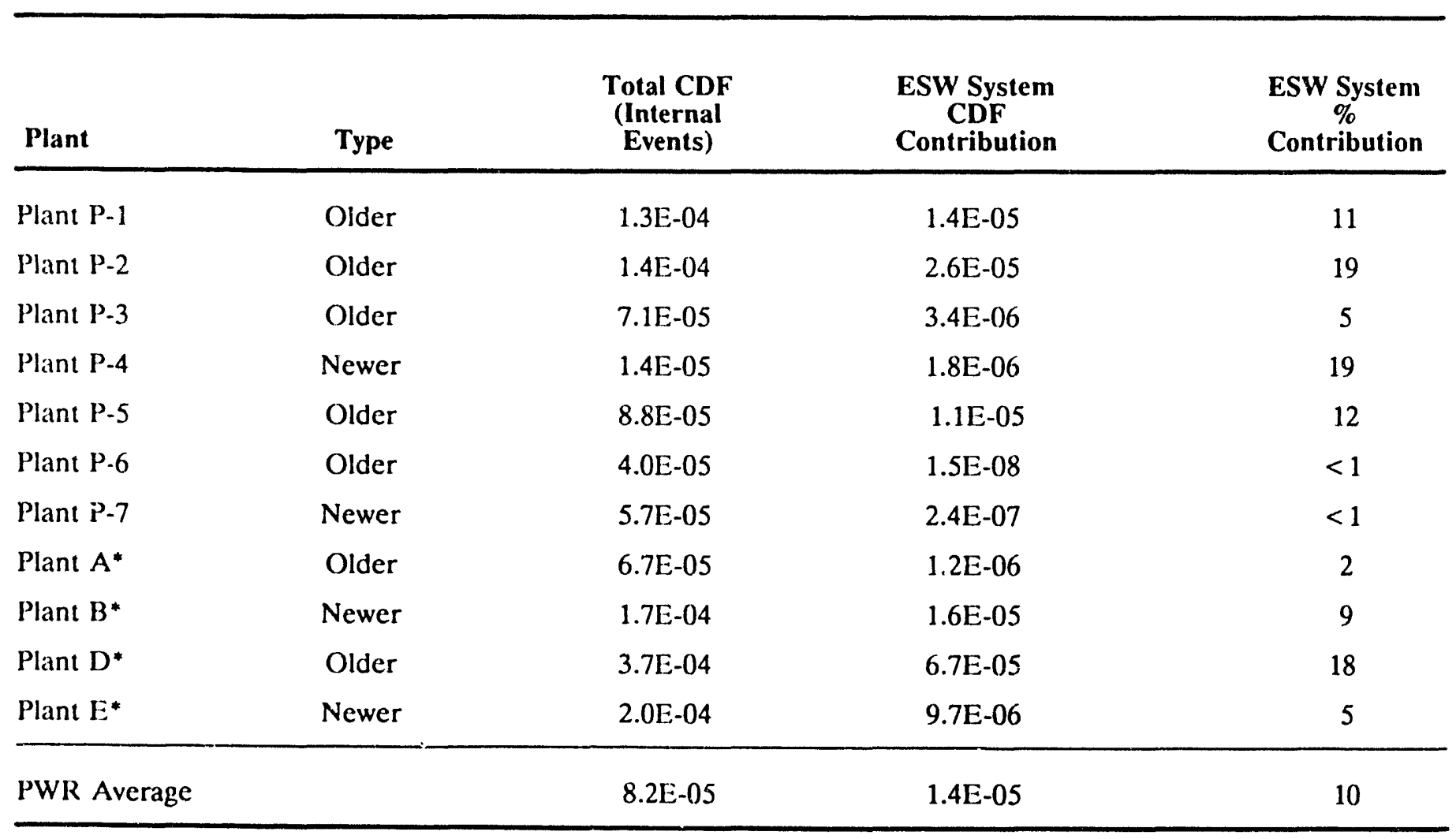

- Plants were identified in NSAC-148 (Ref. 8). PRAs for these plants included internal and external events.

\subsubsection{Dominant Sequences}

Dominant sequences with regard to total CDF due to all causes are distinctly different in PWR and BWR plants.
For PWRs, medium and small loss-of-coolant-accident sequences tend to dominate contribution to total plant internal events CDF (ranging from 30 to 86 percent). 
When considering the contribution of the IESW system to the risk of core damage to PWRs, the ESW system tends to also dominate in these sequences where the ESW system fails to provide cooling to the high and low pressure cooling systems either in the injection phase or in the recirculation phase of operation. That is, the ESW system fails to provide cooling to the injection system pumps or pump room coolers, thereby causing loss of injection; or the ESW system fails to provide cooling to the residual heat removal (RHR) heat exchanger, thercby causing failure of low pressure recirculation.

However, for BWRs the contribution of the ESW system to the risk of core damage is predominantly in sequences where the ESW system fails to provide cooling to the RHR system in the suppression pool cooling mode (due to loss of an ac bus as an initiator or loss of offsite power).

Station blackout sequences were considered in the Generic Issue 23 as the prime accidents that would result in failure of the reactor pump seals of PWRs. However, note that when the GI-153 study reviewed the dominant accident sequences for the contribution of the ESW system to the risk of core damage, station blackout sequences were not considered because safety systems which depend on the ESW system will not be functional following a station blackout regardless of the availability of the ESW system. This may partly explain why the GI-153 study did not reveal the seal failure as one of the dominant sequences as discussed above. Other aspects of the differences between the GI-23 study and the GI-153 study in terms of the risk assessments of the ESW system are discussed in Section 3.4.1.

\subsubsection{ESW System Failure Modes}

The ESW system dominant failure modes found from the review of the 11 NRC-sponsored PRAs tend to have some common aspects in different plants, even though the system configuration for each plant is unique. These failure modes are listed in Table 2.7, together with their relative contributions to internal events CDF at those sites where they were among the dominant contributors. Note that no single common failure mode for all the 11 PiRAs was found.

The two most common ESW system faults were the dependency of the ESW system on motor-operated isolation valves to open on demand to supply cooling water to safety-related loads and failure of the standby service water pumps to start. Two other subtle failure modes are (1) failure to isolate nonessential cooling water loads and (2) failure of cross-tied pumps as a result of back flow through a pump discharge check valve. The first failure mode can result in inadequate cooling of the essential loads because of the diversion of water away from the essential loads and the potential for pump runout and failure. 'The second failure mode can occur if the discharge check valve fails to reclose in one pump train of a multiple pump system where the pumps are all cross-tied. The failure of the check valve to reclose occurs when one of the operating pumps is shut down. This allows flow from the other pump(s) to recirculate back through the idle pump resulting in functional failure of the system.

\subsubsection{Effects of Water Quality on ESW System}

The NRC-sponsored study on service water system aging showed that poor water quality which results in silting, corrosion and fouling can cause ESW system component failures (Ref. 24, 25). The EPRI-sponsored study (Ref. 8) also indicated that water quality has a major effect on the reliability of the ESW system. However, because water quality varies from plant to plant and because generic data instead of plant-specific data were used in the PRAs reviewed for the GI-153 study to quantify the system models, the effect of water quality would not be expected to be a major finding in the GI-153 study. Therefore, water quality problems (c.g., above-average maintenance outage times for the service water system and higher component failures rates) typically would not be accounted for.

Nevertheless, a GI-153 sensitivity analysis was performed for the pilot plant ESW system components partly to determine the importance of water quality problems. The following component failure modes were selected as being susceptible to water quality problems:

$$
\begin{aligned}
& \text { - check valve back leakage } \\
& \text { - } \quad \text { air-operated valve failure to open } \\
& \text { - } \quad \text { air-operated valve unavailability becausc of } \\
& \text { - maintenance } \\
& \text { - mogged manual valve } \\
& \text { - motor-driven pump failure to run } \\
& \text { maintenance }
\end{aligned}
$$

The analysis was performed by adjusting the probabilities of all of the selected failure modes by a multiplier and recalculating the CDF for the existing accident sequence cut sets. Increasing the probabilitics of these failure modes by a factor of 3 resulted in a 40 percent increase in the total CDF from internal events. Increasing the probabilities by a factor of ten increased the total internal events $C D F$ by 150 percent. 'Thus, the sensitivity analysis showed that water quality could have a significant effect on the contribution of the ESW system to CDF, as was also concluded in the EPRI-sponsored report (Ref.8). The insights gained from this analysis support the need to use plant-specific data as indicated in Section 4.3. 
Table 2.7 ESW System Failure Modes Dominant at More Than One Site

\begin{tabular}{|c|c|c|c|}
\hline ESW System Failure Mode & Plant & Type & $\begin{array}{c}\text { Percent } \\
\text { Contribution } \\
\text { to } \\
\text { Internal Events } \\
\text { CDF }\end{array}$ \\
\hline $\begin{array}{l}\text { Failure of ESW system motor-operated or air-operated } \\
\text { isolation valve to open on demand to supply cooling water to } \\
\text { safety-related loads }\end{array}$ & $\begin{array}{l}\text { Plant B-2 } \\
\text { Plant B-3 } \\
\text { Plant B-4 } \\
\text { Plant P-1 } \\
\text { Plant P-5 }\end{array}$ & $\begin{array}{l}\text { BWR } \\
\text { BWR } \\
\text { BWR } \\
\text { PWR } \\
\text { PWR }\end{array}$ & $\begin{array}{r}18 \\
4 \\
7 \\
6 \\
11\end{array}$ \\
\hline Failure of standby service water pump to start & $\begin{array}{l}\text { Plant B-1 } \\
\text { Plant B-3 } \\
\text { Plant B-4 }\end{array}$ & $\begin{array}{l}\text { BWR } \\
\text { BWR } \\
\text { BWR }\end{array}$ & $\begin{array}{l}4 \\
2 \\
3\end{array}$ \\
\hline Common-mode failures of pumps & $\begin{array}{l}\text { Plant B-1 } \\
\text { Plant B-4 } \\
\text { Plant P-4 } \\
\text { Plant P-5 } \\
\text { Plant P-2 } \\
\text { Plant P-3 }\end{array}$ & $\begin{array}{l}\text { BWR } \\
\text { BWR } \\
\text { PWR } \\
\text { PWR } \\
\text { PWR } \\
\text { PWR }\end{array}$ & $\begin{array}{r}5 \\
4 \\
13 \\
1 \\
7 \\
4\end{array}$ \\
\hline $\begin{array}{l}\text { Failure of isolation valve to isolate nonessential cooling } \\
\text { water loads }\end{array}$ & $\begin{array}{l}\text { Plant B-2 } \\
\text { Plant P-3 }\end{array}$ & $\begin{array}{l}\text { BWR } \\
\text { PWR }\end{array}$ & $\begin{array}{r}34 \\
2\end{array}$ \\
\hline Plugged manual valve & $\begin{array}{l}\text { Plant P-1 } \\
\text { Plant P-2 }\end{array}$ & $\begin{array}{l}\text { PWR } \\
\text { PWR }\end{array}$ & $\begin{array}{l}1 \\
2\end{array}$ \\
\hline Unavailability of ESW loop because of maintenance & $\begin{array}{l}\text { Plant B-2 } \\
\text { Plant B-1 }\end{array}$ & $\begin{array}{l}\text { BWR } \\
\text { BWR }\end{array}$ & $\begin{array}{l}12 \\
19\end{array}$ \\
\hline
\end{tabular}

\subsection{Evaluation of Selected Plant-Specific PRAs}

In this section, the staff discusses the evaluation of the contribution of the ESW system to the risk of core damage for Plant B-2 and Plant B-3. These two BWR plants were selected because Plant B-2 represents the upper end in terms of this contribution and Plant B-3 represents the lower end as shown in Table 2.5. Plant B-2 was evaluated under the Unresolved Safety Issue (USI) A-45 program (Ref. 25). The results of the evaluation are summarized here to illustrate the safety significance of the ESW system. A detailed value/impact analysis of Plant B-3, selected as the GI-153 pilot plant, was performed to demenstrate that cost-effective modifications to reduce the contribution of the ESW system to the risk of core dam- age are possible even for a plant with a relatively low risk pertaining to the ESW system.

\subsubsection{Plant B-2}

The ESW system of Plant B-2 includes the reactor building closed cooling water (RBCCW) system and the reactor building service water (RBSW) system. The vulnerabilities of the ESW system were investigated under the USI A-45 program (Ref. 25), and the dominant ESW component failures and unavailabilities were identified as the following:

(1) failure of the RBCCW noncritical header isolation valve (motor-operated valve) to isolate nonsafety loads (31\%) 
(2) failure of the RBCCW isolation valve (two motoroperated valves) to safety loads to open (18\%)

(3) failure of the RBSW noncritical header isolation valve (motor-operated valve) to isolate nonsafety loads $(3 \%)$

(4) unavailability of one of the two RBSW loops because of maintenance (5\%)

(5) unavailability of one of the two RBCCW loops because of maintenance (7\%).

\subsubsection{Contribution of ESW system to Internal Events CDF}

The contribution of each potential vulnerability to the plant internal events CDF is as follows:

\begin{tabular}{cc} 
Vulnerability & $\begin{array}{c}\Delta \text { CDF per } \\
\text { reactor year }\end{array}$ \\
\hline 1 & $9.0 \mathrm{E}-5$ \\
2 & $5.2 \mathrm{E}-5$ \\
3 & $0.9 \mathrm{E}-5$ \\
4 & $1.5 \mathrm{E}-5$ \\
5 & $2.0 \mathrm{E}-5$ \\
\hline & $1.9 \mathrm{E}-4$ \\
\hline
\end{tabular}

The study showed that the modifications to reduce vulnerabilities 1,2 , and 3 above would be cost-effective. These modifications include the following:

- Addition of a bypass line around the normally closed motor-operated isolation valves in the RBCCW pump discharge

- Addition of a second isolation valve to the RBCCW noncritical supply header

- Addition of automatic closure logic to the second isulation valve for the noncritical header of the RBSW system

Implementation of these modifications would reduce the plant's internal events CDF by $1.5 \mathrm{E}-4$ per reactor-year, which represents about 52 percent of the plant total internal events CDF.

\subsubsection{Contribution of ESW system to External Events CDF}

The external events identified under the USI A-45 program included seismic events, firc, internal flood, external flood, extreme wind, and lightning. However, only the vulnerabilities related to scismic events, fire, and external flood were found significant in regard to plant CDF and were evaluated for potential modifications. The proposed modifications related to the ESW system include (1) strengthening of the RBCCW heat exchanger supports, (2) addition of a 1-hour fire barricr around RBSW power cables, and (3) development of procedures for safe shutdown during very high flood crests. Implementation of modifications to the ESW system for external events and for internal events could reduce the plant's total CDF from $4.4 \mathrm{E}-4$ to $1.8 \mathrm{E}-4$ per reactor-year, or a reduction of $2.6 \mathrm{E}-4$ per reactor year. These modifications were found to be cost-effective.

\subsubsection{Plant B-3}

\subsubsection{ESW System Vulnerabilities}

For the GI-153 scoping study (Ref. 9), a detailed value/ impact analysis of a BWR-4/Mark I plant (Plant B-3) was performed. Although similar in general design, the ESW system of Plant B-3 is substantially different from that of Plant B-2. The ESW system of Plant B-3 for safety-related equipment consists of the emergency service water system, the emergency heat sink, the high pressure service water system and the reactor building cooling water system. However, the dominant basic events which contribute to the plant $\mathrm{CDF}$ involve the emergency service water (EMSW) system and the emergency heat sink (EHS) only.

The EMSW system of Plant B-3 is designed to provide cooling water for the diesel-engine coolers and the emergency core cooling systern equipment room coolers during a loss of offsite power. The system consists of two full-capacity pumps installed in parallel and is common to both Units 2 and 3 . The normal suction source for the pumps is a pond. The pump discharge piping consists of two headers with service loops to supply the diesel-engine coolers and selected equipment coolers. A common discharge header routes the system effluent back to the pond. The configuration of the EMSW system is showed in detail in the scoping study report (Ref. 9).

Both EMSW pumps start automatically whenever standby diesel-gencrators are started. One of the EMSW pumps is manually shut off if both pumps are running. Should the EMSW pumps fail, the EMSW may be operated in conjunction with the EHS.

The EHS functions as a backup to the EMSW system. The EHS consists of an induced-draft cooling tower and a full capacity Emergency Cooling Water (ECW) pump. The cooling tower will be used to cool the return water from the ESW system loads, and the ECW pump delivers the cooling water back to the ESW system through the EMSW piping and valving. 
Based on the design and the operational modes of the EMSW system described above, vulnerabilities and associated potential modifications were identified as follows:

Vulnerability 1: Operator Fails to Operate the ECW Pump

Following a loss of offsite power, the ECW pump automatically starts after a 22-second time delay following an emergency diesel generator auto start. If the discharge pressure for the EMSW pumps appears normal, the operator will shutdown the ECW pump. If, later in the accident, the operating EMSW pump trips and the standby EMSW pump fails to start or run, the operator must manually restart the ECW pump. This vulnerability addresses the operator failure to restart the ECW pump following a delayed failure of the EMSW pumps.

\section{Modification 1: Addition of a Third EMSW Pump}

The addition of a third EMSW pump that would auto start on diesel auto start or low EMSW system pressure would increase the reliability of the EMSW system. Such an addition would reduce dependance on operator actions to initiate the emergency heat sink and add flexibility in response to a loss of offsite power accident.

Modification 2: Addition of Standby Auto Actuation Logic for the ECW Pump

The addition of standby auto-actuation logic would demand the ECW pump to auto start and the pump discharge valve to open on low EMSW system pressure after the emergency diesel generator auto start signal has been received. This modification in effect would have the ECW pump respond as if it were a third EMSW pump and would eliminate the dependency of the ECW pump on the operator following a loss of offsite power transient.

Modification 3: Provide Additional Operator Training, Revise Procedures, Add Additional Alarms in the Control Room

This modification would provide additional operator training and revision of procedures to enhance the operators response to conditions requiring the starting of the $\mathrm{ECW}$ pump. Additional alarms and indication would be provided to aid the operator.

\section{Vulnerability 2: Failure to Restore EMSW Components} After Maintenance

Failure to restore an EMSW motor driven pump or EMSW diesel generator cooling components defeats one-half of the EMSW system. Restoration of these components after maintenance is performed using written procedures with independent verification. Functional testing of these components is performed following maintenance to verify operability. Therefore, the failure to restore EMSW components is a direct result of the operator failing to follow plant procedures.

Modification 3: Provide Additional Operator Training and/or Revise Procedures

This is the same modification as proposed for Vulnerability 1.

Vulnerability 3: Discharge Check Valve Failures Fail Cross-Tied EMSW Pumps

This failure of the running EMSW pump is caused by failure (back leakage) of the standby EMSW pump discharge check valve. That is, when the standby pump is secured following auto-actuation with the chosen pump running, the flow from the operating pump recirculates back through the failed check valve and the standby pump and results in functional failure of the operating pump.

Modification 4: Addition of a Second Pump Discharge Check Valve

This modification would provide a sccond pump discharge check valve in series with the existing pump discharge check valve to reduce the probability of this occurrence.

Modification 5: Increase System Functional Testing Frequency for EMSW Pump Discharge Check Valves

This modification would increase the EMSW system test frequency from quarterly (current frequency) to monthly. By doing so, the probability of a check valve failing to reclose would decrease by a factor of three.

\section{Vulnerability 4: EMSW Pump Hardware Faults}

The EMSW consists of two redundant, cross-tied pump trains. The success criteria established is one of two EMSW pumps operating delivering flow or the ECW pump delivering flow to the ESW system. Dominant failure modes generally consist of one EDG failing, which fails one EMSW pump, and the resulting available pump failing to start/run, and the operator fails to initiate the ECW pump.

\section{Modification 1: Addition of a Third EMSW Pump}

This is the same modification as proposed for Vulnerability 1.

Modification 2: Addition of Standby Auto Actuation Logic for the ECW Pump

This is the same modification as proposed for Vulnerability 1 .

Vulnerability 5: Failure of EMSW to Cool the EDGs Due to AOV Failures 
The EMSW provides cooling water to the emergency diesel generators. The EMSW outlet header from each emergency diesel generator contains an air operated isolation valve that is signaled open when its respective diesel generator starts. Failure of this valve to open on diesel start defeats EMSW cooling to that diesel which results in failure of the respective diesel generator. Failure of the diesel generators following a loss of offsite power results in a station blackout.

Modification 6: Addition of a Check Valve in Series to the Diesel Generator AOVs

This modification would remove the demand on the AOVs to open on diesel start by making them normally open valves and installing a check valve in series with the AOV.

Modification 7: Addition of a Swing, Self-Cooled Diesel Generator

This modification consists of the addition of a swing, selfcooled diesel generator that would auto start in the event of loss of normal sources of power to the onsite power system.

The vulncrabilities and the proposed modifications are summarized in Table 2.8 .

\subsubsection{Value/Impact Analysis}

A value/impact analysis was performed for Plant $\mathrm{B}-3$, and the results of the analysis are given in Table 2.9. The ana!ysis is presented in detail in Reference 10 . As can be seen from Table 2.9, Modification 2 scores the lowest value/impact ratio of $\$ 380$ per person-rem (internal and extcrnal events) which represents a cost-effective measure for reducing risk.

Note that the external events CDF for Plant B-3 were dominant for the value/impact analysis. The effect of external events is discussed in the following section.

\subsubsection{Contribution of ESW to External Events CDF}

The scoping study evaluated the external events contributions for Plant B-3 using the analysis provided in NUREG-1150 (Ref. 27). NUREG-1150 provides an analysis of external events including hazards due to earthquakes, fires, external and internal flooding, and extreme winds and tornadoes for Plant B-3. The analysis showed that all external hazards except fire and seismic events are negligible contributors to the risk of core damage. For the scoping study, the fire and seismic events assessments of NUREG-1150 were analyzed to determine the contribution of the ESW failures. The detailed analysis is provided in Reference 10.
For the analysis, ESW system failures that are a direct consequence of the external event and random failures that cause a component to be unavailable at the time of the external event were considered. The analysis showed that the overall fire-induced CDF is 2.0E-05 per reactoryear, of which 65 percem or $1.5 \mathrm{E}-05$ is the contribution of the ESW system. For seismic-induced CDF, using the frequency assumed by Lawrence Livermore National Laboratory (LLNL), the total seismic-induced CDF is 7.7E-05 per reactor-year and the contribution of the ESW system to that amount is $2.4 \mathrm{E}-05$ per reactor-year. If the seismic frequency assumed by EPRI is used, the total seismic-induced CDF is 3.1E-06 per reactor-year and the contribution of the ESW system to that amount is 1.1E-06 per reactor-year.

Table 2.10 shows the contributions of the ESW system to internal and external events CDF. These values are based on the LLNL seismic hazard estimates. As can be seen from Table 2.10, the ESW system contribution to the risk of core damage increases from $1.4 \mathrm{E}-06$ per reactor year for internal events only to $3.8 \mathrm{E}-05$ per reactor year considering both internal and external events. As a result. the value/impact ratio for Modification 2 was reduced from a value of $\$ 3,800$ per person-rem for internal events only to $\$ 380$ per person-rem if both internal and external events were considered.

\subsubsection{Loss of ESW System as Initiator}

Loss of the ESW system as an initiator was not considered in the USI A-45 study and the NUREG-1150 analysis (Ref. 25 an 26). The report on the USI A-45 study did not give a reason for excluding loss of the ESW system as an initiator. NUREG-1150 indicated that, on the basis of a general review, the possible causes for the ESW system being an initiator were unlikcly. No detailcd analysis was performed to substantiate this conclusion.

However, on the basis of the revicw of ESW system operating experience (Ref. 7), the frequency of complcte loss of the ESW system is relatively high (1.8E-02 per reactoryear). Consequently, loss of the ESW system should be considered a credible initiator. Should the effect of the ESW system as an initiator be considered, the proposed modifications would become even more favorable because of the increase of the contribution of the ESW system to the risk of core damage.

\subsubsection{Uncertainty Considerations}

Uncertainty arises from the selection of the database used to determine parameter values, modeling assumptions, and completeness of the analysis. Because the database and model from the previous NRC-sponsored PRAs (NUREG-1150, USI-45, and IRIPP) were used for the GI-153 study, the uncertainties of these PRAs will become the inherent uncertainties of the GI-153 study. 
Table 2.8 ESW System Vulnerabilities and Modifications

Vulnerability

1. Failure of operator to

operate emergency heat sink

- ESW pump hardware faults

- failure to restore ESW components after maintenance

2. Failure of discharge check

valve causing failure of cross-tied ESW pumps

3. Failure of ESW to cool the emergency diesel generators because of failure of air-operated valves
Alternative Modifications

1. Addition of a third emergency service water pump

2 Addition of standby auto-actuation logic for the emergency cooling water pump

3. Additional operator training, revised procedures, and additional alarms in the control room

4. Addition of a second pump discharge check valve

5. Increased system testing frequency

6. Addition of check valves in series to the air operated valves

7. Addition of a swing, self-cooled diesel generator

Table 2.9 Value/Impact Analysis for Individual Modification (Plant B-3)

(Internal and External Events CDF)

\begin{tabular}{clrr}
\hline Modification & $\begin{array}{c}\text { CDF } \\
\text { Per RY }\end{array}$ & $\begin{array}{c}\text { Cost } \\
\$\end{array}$ & $\begin{array}{c}\text { Value/Impact } \\
\text { Ratio } \\
\text { \$/P-REM }\end{array}$ \\
\hline 1 & $9.4 \mathrm{E}-6$ & $12,000 \mathrm{~K}$ & $37 \mathrm{~K}$ \\
2 & $1.2 \mathrm{E}-5$ & $150 \mathrm{~K}$ & $0.38 \mathrm{~K}$ \\
3 & $0.0 \mathrm{E}+0$ & $\mathrm{NA}$ & NA \\
4 & $3.9 \mathrm{E}-6$ & $1,200 \mathrm{~K}$ & $9 \mathrm{~K}$ \\
5 & $2.9 \mathrm{E}-6$ & $35 \mathrm{~K}$ & $3 \mathrm{~K}$ \\
6 & $2.0 \mathrm{E}-6$ & $1,800 \mathrm{~K}$ & $27 \mathrm{~K}$ \\
7 & $1.1 \mathrm{E}-5$ & $21,000 \mathrm{~K}$ & $59 \mathrm{~K}$ \\
\hline
\end{tabular}

Table 2.10 ESW System Contribution to Core Damage Frequency (Plant B-3)

\begin{tabular}{lccc}
\hline & $\begin{array}{c}\text { Plant CI/F } \\
\text { PER } \\
\text { Reactor year }\end{array}$ & $\begin{array}{c}\text { ESW System } \\
\text { Contribution } \\
\text { to CDF }\end{array}$ & $\begin{array}{c}\text { Percent of } \\
\text { ESW System } \\
\text { Contribution }\end{array}$ \\
\hline Internal Events & $4.5 \mathrm{E}-06$ & $1.4 \mathrm{E}-06$ & 31 \\
External Events & $9.7 \mathrm{E}-05$ & $3.7 \mathrm{E}-05$ & 38 \\
Total & $1.0 \mathrm{E}-04$ & $3.8 \mathrm{E}-05$ & 38 \\
\hline
\end{tabular}


The value/impact results for Plant B-2 were taken directly from the USI A-45 study (Ref. 26). The uncertainty analysis was presented in Section 8 of NUREG/CR-4767 (Ref. 26). For Plant B-3, the contribution of the ESW system to the risk of core damage for each alternative modification was analyzed by using the NUREG/CR-4550 (Ref. 28) sequences as appropriate. The costs for engineering, installation, operations and maintenance for implementing the modifications were estimated by using the costs estimated for the USI A-45 study and then multiplied by the consumer price index for the years 1985 to 1992 to account for inflation. The onsite dose (40,000 person-rem) for Plant B-3 was assumed to the same as that used for the similar reactor of the USI-45 study. The methodology for the GI-153 value/impact analysis followed the same methodology used for the USI A-45 study.

A sensitivity study (Ref. 10) for Plant B-3 was performed by varying (1) the estimate of initial cost and of recurring cost, (2) the parameters for replacement power, loss of investment, onsite cleanup, and onsite dosage from an accident, (3) the calculated risk reduction, and (4) the discount rate and remaining plant life: 'The results of the sensitivity analysis are presented in detail in Reference 10. For Modification 2, the results are given in Table 2.11. The central value shown in this table is the value calculated by the scoping study, the low and high values are calculated by varying those parameters and assumptions indicated above using an assigned factor. For instance, a factor of 2 above and below the central values was assigned for the risk reduction, which represents the uncertainties in the PRA. As can be seen from Table 2.11, the value/impact ratio is very sensitive to the PRA uncertainties and is much less sensitive to other parameters (event consequence and cost). It could vary from $\$ 30$ per personrem (high risk reduction) to $\$ 4,000$ per person-rem (low risk reduction), with a mean of $\$ 380$ per person-rem. The results of the sensitivity study indicate that the value/impact analysis for the GI-153 scoping study did not generate any significant additional source of uncertainty. Therefore, decision making on determining whether Modification 2 is favorable will rely on the acceptance of the NUREG/CR-4550 PRA and its associated uncertainties (Ref. 28), which is onc of the NUREG-1150 plants.

Table 2.11 Sensitivity of Modification 2 Cost/Benefit Ratio to Variations in Assumptions for Plant B.3 (Internal and external events CDF) (K\$ per person-rem)

\begin{tabular}{l|c|c|c|c|c|c|c|c|c}
\hline $\begin{array}{c}\text { Calculated Risk } \\
\text { Reductions (Note 1) }\end{array}$ & \multicolumn{3}{|c|}{$\begin{array}{c}\text { Low } \\
\text { (L) }\end{array}$} & \multicolumn{3}{c|}{$\begin{array}{c}\text { Central } \\
\text { (C) }\end{array}$} \\
\hline $\begin{array}{c}\text { Event Consequence } \\
\text { Estimates } \\
\text { (Note 2) }\end{array}$ & L. & C & H & L & C & H & L & C & H \\
Cost & & & & & & & & & \\
Estimates (Note 3) & & & & & & & & & \\
\hline L & 3.6 & 3.3 & 2.7 & .34 & .3 & .22 & .027 & .02 & $<.01$ \\
C & 4.4 & 4.0 & 3.4 & .42 & .38 & .3 & .036 & .03 & .013 \\
H & 6.0 & 5.6 & 4.9 & .59 & .55 & .47 & .053 & .046 & .03 \\
\hline
\end{tabular}

Notes: 1. Central value $=$ values used for the value/impact analysis for the scoping study; Low $=.5 \times$ Central; High $=2.0 \times$ Central. The rationale for these assigned multipliers was discussed in Reference 10 .

2. $\quad$ L.ow $=.2 \times$ Central; High $=5.0 \times$ Central.

3. $\mathrm{L}(\mathrm{w}=.8 \times$ Central; High $=1.6 \times$ Central. 


\section{ESW-RELATED REGULATORY ACTIVITIES}

There are a number of on-going regulatory activities aiming to improve the ESW system reliability. These activities are summarized in the following sections.

\subsection{SWS System Operational Performance Inspection Program}

The NRC has initiated a Service Water System Operational Performance Inspection (SWSOPI) program to satisfy the following objectives ( $\operatorname{Ref} 22$ ):

- verify that the SWS system is capable of meeting thermal and hydraulic design requirements

- identify and evaluate SWS design vulnerabilities

- assess SWS operation, maintenance, surveillance, testing, and associated personnel training

- assess the unavailability of the SWS that is the result of planned maintenance, surveillance, and component failures

- assess the licensee's planned or completed actions in response to GL $89-13$

The NRC staff has completed pilot ESW system inspections at St. Lucie, Ginna, Quad Cities, and South Texas. A common finding from these inspections is that licensees have not been successful in confirming the existing licen:sing basis for their ESW systems. Also, potential single failures that could prevent the ESW system from performing its safety function have been identified (Ref. 22). The NRC staff plans to conduct the SWSOPI program at most sites to ensure that issues pertaining to this system are adequately resolved.

\subsection{Implementation of Generic Letter 89-13 Requirements}

Generic Letter 89-13 requires each licensee to take the following actions:

- implement surveillance and control techniques

- conduct heat transfer testing of ESW cooled heat exchangers

- implement a routine inspection and maintenance program
- confirm that the ESW system will perform its intended function in accordance with the plant's licensing basis

- confirm the adequacy of maintenance practices, operating and emergency procedures, and training

The reliability of the ESW system will be improved when these actions are implemented.

\subsection{Individual Plant Examination Program}

GL 88-20, Supplement 1 (Ref. 29) requested each licensee to perform an Individual Plant Examination (IPE) for severe accident vulnerabilities from internal events. NUREG-1335 (Ref. 30) provides guidance on what each IPE should involve. Related to ESW concerns, licensees are to consider as part of their IPE the following:

- Interfaces and dependencies of front-line systems with the supports systems

- Generic and plant-specific initiating events

- Equipment unavailability because of test and maintenance

- Common-cause failures

- Human failures, both in maintenance and operation and failures to recover and mitigate

- Internal flooding

- As-built, as-operated system configurations

In addition, GL 88-20, Supplement 4 (Ref. 31 ) requires each licensee to perform an Individual Plant Examination of External Events (IPEEE) of their plant. This examination should identify severe accident vulnerabilities resulting from seismic events, internal fires, high winds and tornadoes, external floods and transportation and nearby facility accidents.

The ESW vulnerabilities and associated risks are difficult to extract from a PRA if the specific ESW system insights are not taken into consideration. Therefore, the insights from the GI-153 study are provided in Section 4.3 to serve as guidance for any ESW risk assessment.

\subsection{ESW-Related Generic Issues}

\subsubsection{Generic Issue 23, "Reactor Coolant Pump Seal Failures"}

GI-23 identified loss of cooling water to the reactor coolant pump (RCP) seals as one of the mechanisms causing 
failure of the seals and subsequent seal LOCA following a station blackout accident. The proposed GI-23 resolution is currently applied to PWRs only. For BWRs, the risk associated with seal LOCA was considered insignificant at the time the proposed resolution was issued for public comments; but this position has becn under re-evaluation in response to the public comments. The cooling water to the RCP seals for PWRs is normally provided by the Component Cooling Water (CCW) system which is typically supported by the ESW system for most plants. Therefore, resolution of GI-23 may have direct impact on the assessment of the contribution of the ESW system to the risk of core damage for PWRs. It should be noted that the risk assessment from the GI-153 study reviewed only previous PRAs in the areas related to the ESW system and did not specifically review seal LOCA. These PRAs may not have considered seal LOCA, or they may have considered seal LOCA but used a different leakage model from what was used by GI-23.

\subsubsection{Generic Issue 51, "Improving the Reliability of Open Cycle Service-Water System"}

GI-51 deals with service water system fouling. The problems of biofouling are considered to be resolved by implementing the bascline fouling program, as required by Generic Letter 89-13 (Ref. 5). Therefore, biofouling-related problems were not included in GI-153 scope of work.

\subsubsection{Generic Issue 130, "Essential Service Water Pump Failures at Multi-Unit Sites"}

GI-130 is limited to seven PWR sites of multi-unit configurations with two ESW pumps per plant. This generic issue is considered resolved by issuance of GL 91-13 (Ref. $32)$.

\subsubsection{Generic Issue B-32, "Ice Effects on Safety-Related Water Supplies"}

This issue deals with the concern of the potential effects of extreme cold weather resulting in ice buildup on various water supplies. This issue was evaluated and determined to be subsumed in GI-153.
A review of icing operating experience was conducted and only one LWR operating event was identified. This event (PWR) was caused by icing on traveling screens for the service water intake in 1976 before commercial operation (Table 2.3). No similar icing events were observed to occur after commercial operation. Although this survey indicates that blockage of water supply caused by icing is a rare event, the consequence could be safety significant. Therefore, the effects of icing on the reliability of the ESW system is identified as one of the potential risk contributor to ESW system vulnerabilities (see Section 4.3).

\subsection{Maintenance Rule}

The NRC is issuing for public comment a draft Regulatory Guide DG-1020, "Monitoring the Effectiveness of Maintenance at Nuclear Power Plants," to endorse an industry guidance document (NUMARC 93-01, Revision 2A, dated July 9, 1992), "Industry Guideline for Monitoring the Effectiveness of Maintenance at Nuclear Power Plant," to implement the maintenance rule stated in 10 CFR Part 50.65. The maintenance rule requires commercial nuclear power plant licensees to monitor the effectiveness of maintenance activities for safety-significant plant equipment to minimize the likelihood of failures and events caused by the lack of effective maintenance. The NRC staff believes that NUMARC 93-01 provides methods acceptable for complying with the provisions of the maintenance rule.

Effective maintenance is important to operability, availability, and reliability of safety equipment. It is especially important to the ESW system because the system involves a raw water supply. As indicated carlier, review of operating experience showed that deposition of sediment, biofouling, corrosion and erosion, and intrusion of foreign matcrial and debris has caused failure and degradation of the system. Effective maintenance is expected to mitigate these causes and improve the ESW system reliability. Although GL 89-13 and the SWSOPI program have previously emphasized the need for effective maintenance, implementation of the maintenance rule by following the NUMARC 93-01 guidance would further strengthen this important area. 


\section{INSIGHTS}

The insights gained from the scoping study discussed in Section 2 are summarized in the following sections:

\subsection{Contribution of the ESW System to the Risk of Core Damage}

- The contribution of the ESW system to the risk of core damage is significant for some BWRs as well as for some PWRs (greater than about 1.0E-5 per reactor year).

- The ESW system appears to be more important for BWRs than for PWRs in terms of the contribution of the ESW system to internal events CDF (1.4E-06 to 2.7E-04 per reactor-year for BWR plants compared with 1.5E-08 to 6.7E-05 per reactor-year for PWR plants).

- The contribution of the ESW system to the risk of core damage is higher for older plants (operating date before 1976) than that for newer plants (averages as 38 percent for older BWRs, 18 percent for newer BWRs and 12 percent for older PWRs, 7 percent for newer PWRs).

- The contribution of the ESW system to the risk of core damage appears to be plant specific.

- External events could affect substantially the total contribution of the ESW system to the risk of core damage. For the pilot plant, external events increased this contribution more than an order of magnitude (from 1.4E-06 to 3.8E-05 per reactor-year). However, the impact of external events CDF could vary substantially from plant to plant.

- Loss of the ESW system was not considered as an initiating event in the NRC-sponsored PRAs (Ref. 9). Should loss of this system be included in the PRAs, the estimated contribution of the ESW system to the risk of core damage is expected to increase.

- The value/impact analysis for the pilot plant demonstrates that cost-effective measures are possible, even for a plant with a relatively low internal events CDF.

\subsection{Dominant Sequences and Other Factors Influencing the ESW System Reliability}

- Dominant sequences with regard to total CDF due to all causes are distinctly different in PWR and BWR plants. When considering the contribution of the ESW system to the risk of core damage at PWRs, sequer: $2 s$ involving small and medium LOCA tend to be dominant. However, for BWRs, the contribution of the ESW system to the risk of core damage is predominant in sequences involving loss of an ac bus as an initiator or loss of offsite power.

- The ESW system dominant failure modes found from the review of the NRC-sponsored PRAs tend to have some common aspects in different plants (see Table 2.7), even though the system configuration for each plant is unique. The two most common ESW system faults were the dependency of the ESW system on motor-operated isolation valves to open on demand to supply cooling water to safety-related loads and failure of the standby service water pumps to start. Two other subtle failure modes are (1) failure to isolate nonessential cooling water loads and (2) failure of cross-tied pumps as a result of back flow from a failed pump discharge check valve.

- Water quality could have a significant effect on the contribution of the ESW system to CDF, as was also concluded in the EPRI-sponsored report (Ref.8). Thus, where water quality is poor, plant-specific equipment failure data should be used in lieu of generic data.

\subsection{ESW-Related Risk Data from PRA Reports}

The insights from extracting the ESW-related risk data from previous NRC-sponsored PRAs and reviewing the IPE submittals result in the fol'owing list which provides the areas important to determining ESW system reliability:

- interfaces and dependencies of front-line systems on the ESW system and the risk contribution resulting from these system interfaces and dependencies

- initiating events (internal and external) including appropriate ESW system failures, such as icing or blockage of an intake screen, and the risk contribution resulting from these initiating events

- dominant sequences that involve failures or degradation of the ESW system 
- ESW train/subsystem unavailability because of maintenance while at power

- the effect of water quality on the ESW system components and plant CDF

- operator errors, required manual operations, maintenance, and recovery actions involving the ESW system. In particular, the need to isolate nonessential cooling loads during accident conditions should be considered.
- a fault tree model for the ESW system. The model should address vulnerabilities of the ESW system to single failures and should consider subtle failures, such as bypass flow through an idle pump and failed check valves in cross-ticd pump discharge headers.

- plant-specific or generic data used for ESW components and initiators, such as water quality problems

- the capability of the methodology to identify vulnerabilities associated with loss of the ESW system

- uncertainties and sensitivities of the PRA 


\section{RECOMMENDATION}

The staff recommends that the insights from Gl-153 regarding the contribution of the ESW system to the risk of core damage serve as a complement to the SWSOPI program to assist in such areas as determining inspection priorities. Other GI-153 information such as dominant sequences, ESW failure modes, and the effects of water quality could also assist the program in identifying and evaluating $\mathrm{ESW}$ vulnerabilities. In addition we note that the plant-specific PRA developed under the Individual Plant Examination (IPE) program is also a meaningful complement to the SWSOPI program to achieve one of its objective, i.e., to identify and evaluate the ESW system vulnerabilities.
With due regard for the insights from GI-153, the ESW system operability, availability and reliability can be improved significantly by implementing the SWSOPI program, Gencric Letter 89-13 requirements, the IPE program, the GI-23 rule-making, the maintenance rule, and the industry sponsored EPRI research program results. Therefore, the staff concludes that ESW system reliability is being adequately addressed by the on-going regulatory and industry initiatives. As a result, the objective of GI-153 is achieved and the issue should be considered "RESOLVED." The need for future action(s) on ESW system reliability is expected to be determined from these on-going programs. 


\section{REFERENCE}

1. U.S. Nuclear Regulatory Commission, NUREG/ CR-5526, "Analysis of Risk Reduction Measures Applied to Shared Essential Service Water Systems at Multi-Unit Sites," Brookhaven National Laboratory, June 1991.

2. U.S. Nuclear Regulatory Commission, NUREG/ CR-2797, "Evaluation of Events Involving Service Water System in Nuclear Power Plant," Oak Ridge National Laboratory, November 1982.

3. IE Bulletin 80-24, U.S. Nuclear Regulatory Commission November 21, 1980.

4. IE Bulletin 81-03, U.S. Nuclear Rigulatory Commission, April 10, 1981.

5. Generic Letter 89-13, "Service Water System Problems Affecting Safety Related Equipment," U.S. Nuclear Regulatory Commission, July 18, 1989.

6. NUREG-0933, "A Prioritization of Generic Safety Issues," U.S. Nuclear Regulatory Commission, June 1989.

7. U.S. Nuclear Regulatory Commission, NUREG-1275, "Operating Experience Feedback Report-Service Water System Failure and Degradations," Vol. 3, November 1988.

8. Elcctric Power Research Institute and Nuclear Safety Analysis Center, NSAC-148, "Service Water Systems and Nuclear Plant Safety," prepared by Pickard, Lowe and Garrick, Inc., May 1990.

9. U. S. Nuclear Regulatory Commission, NUREG/ CR-5910, "Loss of Essential Service Water in LWRs (GI-153) Scoping Study," Sandia National Laboratory, August 1992.

10. Science and Engineering Associates, Inc., SEASFLR-92-013, Rev. 1, "Supplemental Study of Generic Issue 153, Loss of Essential Service Water in LWRs," August 1992.

11. U. S. Nuclear Regulatory Commission, Memorandum from E. L. Jordan to E. S. Beckjord, "Implementation of the Safety Goals," September 6, 1990.

12. U. S. Nuclear Regulatory Commission, "Safety Goals for the Operation of Nuclear Power Plants,"
Policy Statement, Federal Register, Vol. 51, p. 26044, August 4, 1986.

13. U. S. Nuclear Regulatrory Commission, Memorandum from J. Heltemes to R. Bernero et. al., "Regulatory Aralysis Guidelines," July 10, 1992.

14. U. S. Nuclear Regulatory Commission, NUREG/ CR-2497, ORNL/NSIC-182, Volume 1, "Precursors to Potential Severe Core Damage Accidents: 1969-1979, A Status Report," Oak Ridge National Laboratory, June 1982.

15. U. S. Nuclear Regulatory Commission, NUREG/ CR-3591, "Precursors to Potential Severe Core Damage Accidents: 1980-1981, A Status Report," Oak Ridge National Laboratory, Volumes 1 and 2, July 1984.

16. U. S. Nuclear Regulatory Commission, NUREG/ CR-4674, "Precursors to Potential Severe Core Damage Accidents: 1984, A Status Report," Oak Ridge National Laboratory, Volumes 3 and 4, May 1987.

17. U. S. Nuclear Regulatory Commission, NUREG/ CR-4674, "Precursors to Potential Severe Core Damage Accidents: 1985, A Status Report," Oak Ridge National Laboratory, Volumes 1 and 2, De- cember 1986.

18. U. S. Nuclear Regulatory Commission, NUREG/ CR-4674, "Precursors to Poiential Severe Core Damage Accidents: 1986, A Status Report," Oak Ridge National Laboratory, Volumes 5 and 6, May 1988.

19. U. S. Nuclear Regulatory Commission, NUREG/ CR-4674, "Precursors to Potential Severe Core Damage Accidents: 1987, A Status Report," Oak Ridge National Laboratory, Volumes 7 and 8, July 1989.

20. U. S. Nuclear Regulatory Commission, NUREG/ CR-4674, "Precursors to Potential Severe Core Damage Accidents: 1988, A Status Report," Oak Ridge National Laboratory, Volumes 9 and 10, February 1990.

21. U. S. Nuclear Regulatory Commission, NUREG/ CR-4674, "Precursors to Potential Severe Core Damage Accidents: 1989, A Status Report," Oak Ridge National Laboratory, Volumes 11 and 12, August 1990. 
22. SIECY-92-355, "Implementing Service Water System Operational Performance Inspection (SWSOPIs), October 20. 1992.

23. U. S. Nuclear Regulatory Commission, Information Notice 92-49: Recent Loss or Severe Degradation of Service Water Systems, July 2, 1992.

24. U. S. Nuclear Regulatory Commission, NUREG/ CR-5643, "Insights Gained from Aging Rescarch," Brookhaven National I aboratory, March 1991.

25. U. S. Nuclear Regulatory Commission, NUREG/ CR-5379, Vol. 2 "Nuclear Plant Service Water System Aging Degradation Assessment," Pacific Northwest Laboratory. October 1992.

26. U. S. Nuclear Regulatory Commission, NUREG/ CR-4767, "Shutdown Decay Heat Removal Analysis of a General Electric BWR4/Mark l," Sandia National Laboratory, July 1987.

27. U.S. Nuclear Regulatory Commission, NURE:G-1150, "Severe Accident Risks: An Assessment of Five U.S. Nuclear Power Plants," Volumes 1 and 2. December 1990.
28. U. S. Nuclear Regulatory Commission, NUREG/ CR-4550, "Analysis of Core Damage Frequency: Peach Bottom. Unit 2, Internal Events," Sandia National I aboratory, Vol. 4, Rev. 1, August 1989.

29. Generic Letter 88-20, Supplement 1 "Individual Plant Examination for Severe Accident Vulnerabilities-10 CFR 50.54(f)," U.S. Nuclear Regulatory Commission, August 29, 1989.

30. U.S. Nuclear Regulatory Commission, NUREG-1335, "Individual Plant Examination Submittal Guidance," July 1989.

31. Generic Letter 88-20, Supplement 4 "Individual Plant Examination of External Events (IPEEE) for Severe Accident Vulnerabilities-10 CFR 50.54(f)," U.S. Nuclear Regulatory Commission, June 28, 1991.

32. Generic Letter 91-13, "Request for Information Related to the Resolution of Generic Issue 130, 10 CIR 50.54(I)," U.S. Nuclcar Regulatory Commission, September 19, 1991. 


\begin{tabular}{|c|c|}
\hline $\begin{array}{l}\text { NRC FORM } 335 \\
(2-89) \\
\text { NP.CM } 1102 \\
3201,3202\end{array}$ & $\begin{array}{l}\text { U.S. NUCLEAR REGULATORY COMMISSION } \\
\text { BIBLIOGRAPHIC DATA SHEET } \\
\text { (See instructions on the reverse) }\end{array}$ \\
\hline
\end{tabular}

2. TITLE AND SUBTITLE

Regulatory Analysis for the Resolution of Generic Issue 153:

Loss of Essential Service Water in LWRs
1. REPORT NUMBER

(Assigned by NRC, Add Vol.

Supp., Rev., and Addendum 'Num-

bers, if any.'

NUREG-1461

3. DATE REPORT PUBLISHED

\begin{tabular}{l|l} 
MONTH & YEAR
\end{tabular}

August

1993

4. FIN OR GRANT NUMBER

6. TYPE OF REPORT

7. PERIOD COVERED (Inclusive Dates) 8. PERFORMING ORGANIZATION - NAME AND ADDRESS (If NRC, provide Division, Office or Region, U.S. Nuclear Regulatory Commission, and
mailing address; if contractor, provide name and mailing address.)

Division of Safety Issue Resolution

Office of Nuclear Regulatory Research

U.S. Nuclear Regulatory Commission

Washington, DC 20555-0001 9. SPONSORING ORGANIZATION - NAME AND ADDRESS (If NRC, type "Same as above" : if contractor, provide NRC Division, Office or Region,
U.S. Nuclear Regulatory Commission, and mailing address.)

Same as above

10. SUPPLEMENTARY NOTES

11. ABSTRACT (200 words or less)

In this report, the staff of the U.S. Nuclear Regulatory Commission provides a regulatory analysis for the proposed resolution of Generic Issue 153 (GI-153), "Loss of Essential Service Water in LWRs." GI-153 deals with the concerns pertaining to the reliability of essential service water (ESW) system and related problems for all light water reactors except the ceven multi-unit sites addressed by GI-130. "Essential Service Water Pump failures at Multi-Unit Sites." On the basis of the technical findings of a scoping study for GI-153, the staff recommends that the insights gained from the study serve as a complement to the on-going ESW performance inspection program. The staff also concludes that ESW system reliability is being addressed by various on-going regulatory programs. Therefore, the staff recommends that GI-153 should be considered "RESOLVED." The need for future action(s) on ESW reliability is expected to bc determined from these on-going programs.

Regulatory Analysis for Generic Issue 153

LWRs

Essential service water (ESW) 

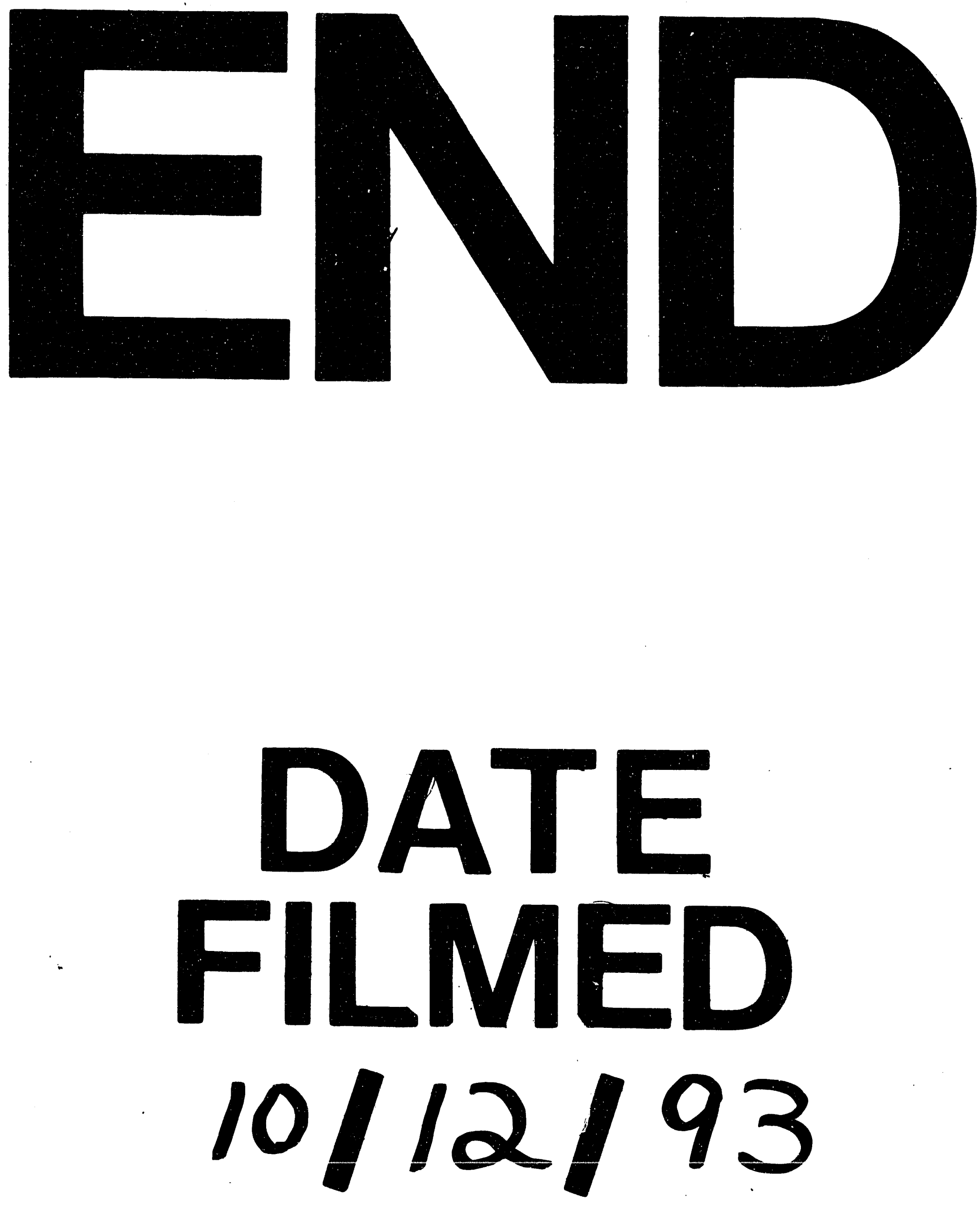

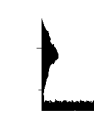


